\title{
INFLUENCE OF CHROMIUM SUPPLEMENTATION ON THERMO-RESPIRATORY RESPONSE AND SOME BLOOD PARAMETERS OF SHEEP EXPOSED TO EXERCISE UNDER DIRECT SUNLIGHT
}

\author{
M. A. Kobeisy ${ }^{1}$, I. A. Soliman ${ }^{1}$ and M. A. Abdulaziz ${ }^{2}$ \\ 1- Animal Production Department, Faculty of Agriculture, Assiut University, Assiut, \\ Egypt, 2- Animal Production Department, Faculty of Agriculture, Aden University, \\ Aden, Yemen
}

\section{SUMMARY}

This study was carried out to investigate the effect of dietary Cr-supplementation on respiration rate $(R R)$ rectal $(R T)$ and skin (ST) temperatures and some blood parameters in sheep exposed to exercise under direct sunlight. Twenty eight Saidi ewes were used in this study. The animals were divided into two treatment groups. A control group with no Cr supplementation and a treated group, supplemented by 250 ppb of Cr as chromium picolinate in concentrate feed mixture. Both groups were fed according to the NRC allowances for 4 weeks. During the last week of treatment, the animals were exposed to exercise under direct sunlight from 11.00 to $13.00 \mathrm{~h}$, during two days. Respiration rate, $R T$ and $S T$ were recorded just before and after exposure. Also, blood samples were taken for $\mathrm{Hb}$ and serum concentrations of total protein, albumin, urea-N, glucose, cholesterol, aspartiate aminotransferase (AST) and alanine aminotransferase (ALT) determinations. Data were statistically analyzed using general linear model (GLM) procedure of SAS. Respiration rate, RT and ST revealed higher $(p<.01)$ values after exposure to exercise than those before exposure in both groups. However, Cr supplemented animals tended to have high increase in $R R$ (172 vs 165\%) and low increase in rectal temperature $\left(0.8\right.$ vs $\left.1.1^{\circ} \mathrm{C}\right)$ due to exercise compaired with controls. Hemoglobin and serum, total protein and ureanitrogen were not significantly affected by treatment. However, serum albumin increased significantly after exercise, such increase was more pronounced in $\mathrm{Cr}$ supplemented animals. Exercise decreased serum globulin in both groups. Serum glucose concentration increased by about $82 \%$ and $51 \%$ in control and Cr-pic supplemented groups, respectively. Both exercise and $\mathrm{Cr}$ supplementation decreased $(P<0.05)$ serum cholesterol concentrations. Chromium supplementation decreased both AST and ALT concentrations. However, exercise increased AST concentration by about 2.9 and 2.0 folds in control and Cr-supplemented animals, respectively.

Keywords: Sheep, Cr feed supplement, blood, exercise, thermo-respiratory response.

\section{INTRODUCTION}

Chromium activates the ability to regulate blood glucose by improving insulin function (Subiyatno et al. 1996, Depew et al. 1998 and Hayirli et al. 2001) and decreasing cortisol secretion (Chang and Mowat, 1992). According to this function chromium has anabolic effect on lean body mass and catabolic effect on body fat

Issued by The Egyptian Society of Animal Production 
(Etchalong et al. 1995). Calves fed $\mathrm{Cr}$ had high glucose disappearance indexes (Bunting et al. 2000). This result is mainly due to high insulin secretion in Crsupplemented animals (Depew et al. 1998). Such results suggest a role for $\mathrm{Cr}$ in body homeostasis during heat stress. There is no available information on the effect of $\mathrm{Cr}$ during exercise. This study aims to investigate the effect of $\mathrm{Cr}$ picolinate on thermo-respiratory responses and some blood parameters in sheep subjected to heat stress, exercise under direct sunlight.

\section{MATERIALS AND METHODS}

\section{Animals and treatments:}

Twenty eight Saidi (Upper Egypt sheep) ewes were classified into two treatment groups (14 each). A control group with no $\mathrm{Cr}$ supplementation and a treated group, supplemented by $250 \mathrm{ppb}$ of $\mathrm{Cr}$ as chromium picolinate in concentrate feed mixture. Both groups were fed according to the NRC (1985) allowances for 4 weeks in june. During the last week of treatment, the animals were exposed to exercise under direct sunlight for two days. Exercise was by walking for 2 hours $(4 \mathrm{~km} / \mathrm{h})$ from 11.00 to $13.00 \mathrm{~h}$. In june, average ambient air temperature and relative humidity during exercise were $33.4^{\circ} \mathrm{C}$ and $29.5 \%$, respectively.

\section{Thermo-respiratory response:}

Respiration rate (RR) was determined by counting the flank movements for one minute. Rectal temperature (RT) was measured by using a clinical thermometer. Skin temperature (ST) was measured by using telethermometer. All measurements were recorded just before and after exercise.

\section{Blood samples and analysis:}

Blood samples were taken just before and after exercise and transfered to two vials, one without EDTA, and the other contained EDTA. Serum was then separated from the whole blood (vial without EDTA) by centrifugation at $4000 \mathrm{rpm}$ for $15 \mathrm{~min}$, frozen and stored at $-20^{\circ} \mathrm{C}$ until subsequent analyses. Hemoglobin $(\mathrm{Hb})$ concentration ( $\mathrm{g} / \mathrm{dl})$ was determined by using kits supplied by Diamond Diagnostics (Egypt). Serum total protein, albumin, urea-N, glucose, cholesterol, aspartate aminotransferase (AST) and alanine aminotransferase (ALT) concentrations were determined using test kits supplied by Diamond Diagnostics (Egypt). Serum globulin concentration was obtained by difference between serum total protein and albumin.

Data were statistically analyzed using general linear model (GLM) procedure of SAS (1981). The following model was used:

$Y_{i j}=\mu+A_{i}+B_{j}+A B_{i j}+E_{i j}$, where $Y_{i j}=$ experimental observation, $\mu=$ general mean, $A_{i}=$ effect of $\mathrm{Cr}, \mathrm{B}_{\mathrm{j}}=$ effect of exercise under solar radiation, $\mathrm{AB}_{\mathrm{ij}}=$ effect of interaction between $\mathrm{Cr}$ and exercise under solar radiation and $\mathrm{E}_{\mathrm{ij}}=$ error.

\section{RESULTS AND DISCUSSION}

\section{Thermorespiratory response:}

Exercise under solar radiation increased $(\mathrm{P}<0.01) \mathrm{RR}$, RT and ST in both $\mathrm{Cr}-$ treated animals and controls (Table 1). Such increase in RT was mainly attributed to the accumulation of heat in the body due to the incease in metabolic heat production 
by muscular activity (exercise) and that added by solar radiation (sun exposure), consequently, increased core body temperature (Kobeisy et al., 1997). However, Cr supplemented animals tended to have high increase in RR (172 vs. 165\%) and low increase in RT $\left(0.8\right.$ vs. $\left.1.1{ }^{\circ} \mathrm{C}\right)$ due to exercise with sun exposure. This result means that dietary chromium picolinate may be useful during heat stress, since it increased blood glucose for rapid utilization by respiratory muscles during heat stress. This mechanism may be mediated through enhancement insulin secretion, consequently glucose clearance rate (Depew et al., 1998 and Bunting et al., 2000).

Table 1. Effect of chromium supplementation on thermorespiratory response of sheep exposed to exercise under direct solar radiation

\begin{tabular}{lccccccc}
\hline Item & \multicolumn{2}{c}{ Control* $^{*}$} & \multicolumn{2}{c}{ Cr-Picolinate } & \multicolumn{3}{c}{ ANOVA } \\
\cline { 2 - 8 } & Before & After & Before & After & Cr & Ex & CrxEx \\
\hline RR & $87.1 \mathrm{~b}$ & $230.4 \mathrm{a}$ & $80.8 \mathrm{~b}$ & $219.7 \mathrm{a}$ & .08 & .01 & .65 \\
RT & $39.1 \mathrm{~b}$ & $40.2 \mathrm{a}$ & $39.3 \mathrm{~b}$ & $40.1 \mathrm{a}$ & .51 & .01 & .35 \\
ST & $36.0 \mathrm{~b}$ & $38.0 \mathrm{a}$ & $35.3 \mathrm{~b}$ & $37.8 \mathrm{a}$ & .04 & .01 & .24 \\
\hline
\end{tabular}

*Values are Least-square means (LSM)

Before $=$ before exercise, after $=$ after exercise, $\mathrm{Cr}=$ chromium, $\mathrm{Ex}=$ exercise

$\mathrm{RR}=$ respiration rate, breath $/ \mathrm{min}, \mathrm{RT}=$ rectal temperature, ${ }^{\circ} \mathrm{C}$

$\mathrm{ST}=$ skin temperature ${ }^{\circ} \mathrm{C}$

a,b, Means in the same raw with different superscripts are significantly different $(\mathrm{P}<0.01)$.

Some blood traits:

Exposure to exercise under direct sunlight had no significant effect on $\mathrm{Hb}$ concentration. However $\mathrm{Cr}$ treatment increased hemoglobin concentration $(\mathrm{P}<0.05$, Table 2).

Table 2. Effect of chromium supplementation on some blood constituents of sheep exposed to exercise under direct solar radation

\begin{tabular}{lccccccc}
\hline \multirow{2}{*}{ Item } & \multicolumn{3}{c}{ Control* } & \multicolumn{3}{c}{ Cr-Picolinate* } & \multicolumn{3}{c}{ ANOVA } \\
\cline { 2 - 8 } & Before & After & Before & After & Cr & Ex & CrxEx \\
\hline Hemoglobin,g/dl & 8.6 & 9.1 & 9.7 & 9.6 & .05 & .66 & .54 \\
Total protein, g/dl & 7.33 & 7.23 & 7.21 & 6.85 & .36 & .39 & .61 \\
Albumin, g/dl & $3.71 \mathrm{~b}$ & $3.98 \mathrm{a}$ & $3.67 \mathrm{~b}$ & $4.08 \mathrm{a}$ & .67 & .01 & .37 \\
Globulin, g/dl & $3.62 \mathrm{a}$ & $3.25 \mathrm{ab}$ & $3.55 \mathrm{a}$ & $2.76 \mathrm{~b}$ & .27 & .02 & .40 \\
Urea-N,mg/dl & 50.36 & 53.79 & 48.83 & 48.45 & .08 & .41 & .33 \\
Glucose,mg/dl & $51.12 \mathrm{c}$ & $93.13 \mathrm{a}$ & $55.05 \mathrm{c}$ & $82.84 \mathrm{~b}$ & .27 & .01 & .01 \\
Cholesterol,mg/dl & $101.64 \mathrm{a}$ & $80.18 \mathrm{bc}$ & $88.03 \mathrm{ac}$ & $81.93 \mathrm{bc}$ & .34 & .02 & .22 \\
AST,u/l & $18.14 \mathrm{c}$ & $52.86 \mathrm{a}$ & $16.62 \mathrm{c}$ & $33.38 \mathrm{~b}$ & .01 & .01 & .01 \\
ALTu/l & $5.21 \mathrm{a}$ & $5.93 \mathrm{a}$ & $4.00 \mathrm{~b}$ & $3.62 \mathrm{~b}$ & .01 & .64 & .17 \\
\hline
\end{tabular}

*Values are Least-square means (LSM)

Before $=$ before exercise, After $=$ after exercise, $\mathrm{Cr}=$ chromium, $\mathrm{Ex}=$ exercise

$\mathrm{AST}=$ aspartate aminotransferase and $\mathrm{ALT}=$ alanine aminotransferase.

$\mathrm{a}, \mathrm{b}, \mathrm{c}$ Means in the same raw with different superscripts are significantly different $(\mathrm{P}<0.05)$. 
Chromium supplementation or exposure to exercise had no effect on serum total protein, however exposure to exercise under direct sunlight increased $(\mathrm{P}<0.01)$ serum albumin in both control and Cr-pico treated animals. This increase was more pronounced in $\mathrm{Cr}$ - treated animals (Table 2). Serum globulin decreased after exposure but such decrease was significant in $\mathrm{Cr}$-treated animals. High albumin concentration in Cr- treated animals, particularly after exercise is a useful physiological mechanism during heat stress. Blood albumin concentration control the osmotic pressure of blood and compensate for the loss of water which occurre during evaporative cooling mehanism (Khalifa, 1996).

In Cr-treated animals, serum urea-N concentration tended to be lower than that of controls, both before and after exercise, however the difference was not statisticaly significant (Table 2). Similarly, Amoikon et al. (1995) found that plasma urea-N concentration was decreased in pigs fed cr-picolinate.

Serum glucose concentration increased by about $82 \%$ in control and in less level $(51 \%)$ in Cr-supplemented group, in response to exercise under direct sunlight (Table 2). Depew et al. (1998) and Hayirli et al. (2001) attributed this chromium effects to increased insulin secretion, consequently enhanced glucose clearance rate. (Depew et al., 1998, Bunting et al., 2000 and Hayirli et al., 2001). In addition, Chromium supplementation decreased cortisol secretion as stated by Chang and Mowat (1992). However, high blood glucose after exercise under direct sunlight is a normal physiological reponse due to short exposure to heat stress and/or high cortisol secretion, to provide more metabolic substrates necessary for survival under such condition (Hadley, 1984 and Kobeisy et al., 1997).

Exercise under direct solar radiation decreased serum colesterol concentrations by about $21 \%$ and $7 \%$ in control and Cr- supplemented animals, respectively (Table 2), in agreement with Kobeisy et al. (2001) who reported that heat stress by solar radiation decreased serum cholesterol concentration by about $13 \%$ in Saidi sheep. The decrease of serum cholesterol concentration due to heat stress may be attributed to the increase of $\mathrm{ACTH}$, during heat stress, resulting in enhanced adrenal steroid synthesis for which cholesterol is precursor (Harper et al., 1977). Before exercise, Cr-supplemented animals tended to have lower serum cholesterol concentration compared with controls. Chromium picolinate supplementation decreased serum cholesterol by about $13 \%$. Also in lambs, Etchalong et al. (1995) found that plasma cholesterol concentration was decreased by about $17 \%(\mathrm{P}<0.01)$ due to $\mathrm{Cr}$-treatment. In addition, Bunting et al. (1994) found that total plasma cholesterol was lower $(\mathrm{P}<0.05)$ in $\mathrm{Cr}$ - fed animals, at wk 4 and wk 6 of the experimental period (about 8 weeks) in Holstein calves and heifers, respectively.

\section{Serum transaminases (AST and ALT):}

Exercise under solar radiation increased $(\mathrm{P}<0.01)$ serum AST concentration by about 2.9 and 2.0 folds for control and Cr-treated animals, respectively (Table 2). This increase may be a support to the increase of glucose demand or the metabolic reaction during heat stress to support high-energy cost of panting (More et al. 1980). Similarly, serum AST concentration increased due to direct exposure to solar radiation in sheep (Kobeisy et al. 2001) and in Jersey calves (Kobeisy, 1994). However, exposure to exercise under direct sunlight had no significant effect on serum ALT concentration in both group of animals. Although, Cr-pic-fed animals, 
both before and after exposure, had lower $(\mathrm{P}<0.01)$ ALT concentration than controls. Chromium supplementation decreased both AST and ALT concentrations (Table 2).

\section{REFERENCES}

Amoikon, E. K., J. M. Fernandez, L. L. Southern, D. L. Thompson Jr., T. L. Ward and B. M. Olcott, 1995. Effect of chromium tripicolinate on growth, glucose tolerance, insulin sensitivity, plasma metabolities and growth hormone in pig. J Anim. Sci., 73:1123-1130.

Bunting, L. D., T. A. Tarifa, B. T. Crochet, J. M. Fernandez, C. L. Depew and J. C. Lovejoy, 2000. Effect of dietary inclusion of chromium propionate and calcium propionate on glucose disposal and gastrointestinal development in dairy calves. J. Dairy Sci., 83:2491-2498.

Bunting, L. D., J. M. Fernandez, D. L. Thompson, Jr, L. L. Southern, 1994. Influence of chromium picolinate on glucose usage and metabolic criteria in growing Holstein calves. J. Anim. Sci. 72:1591-1599.

Chang, X. and D. N. Mowat, 1992. Supplementation chromium for stressd and growing feeder calve. J. Anim. Sci., 70:559-565.

Depew, C. L. , L. D. Bunting, J. M. Fernandez, D. L. Thompson, Jr. and R. W. Adkinson, 1998. Performance and metabolic responses of young dairy calves fed diets supplemented with chromium tripicolinate. J. Dairy Sci., 81:2916-2923.

Etchalong, L. J. M. Fernandez, L. D. Bunting, 1995. Influence of chromium tripicolinate on glucose metabolism and nutrient partitioning in growing lambs. J. Anim. Sci.73:2694-2705.

Hadley, M. E. (Ed.), 1984. Adrenal hormones, In: Endocrinology, pp 344-374, Prentice-Hall, Inc., England Cliffs., New Jersy, UK.

Harper, M. A., V. W. Rodwell and P. A. Mayes, 1977. Review of Physiological Chemistry $16^{\text {th }}$ ed., Lange Medical Publications, California, pp.76-79, 454, 569570.

Hayirli, A. , D. R. Bremmer, S. J. Bertics, M. T. Socha and R. P. Grummer, 2001. Effect of chromium supplementation on production and metabolic parameters in periparturient dairy cows. J Dairy Sci. 84:1218-1230.

Khalifa, H. H., 1996. The adaptive responses of local and Finn crossbred sheep. In symposium on : Use of exotic breeds in improving sheep production, finnsheep as a case study. April, 22-23, Cairo, Egypt.

Kobeisy, M.A., 1994. effect of exposure to solar radation on some physiological and hematological parameters in suckling Jersey calves fed ascorbic acid. Vet Med. J. Giza, Egypt, 42:285-291.

Kobeisy, M. A., G. A. Abd El-Hafez, F. F. El-Hommosi and H. S. Badawy, 2001. Influence of solar radiation and feeding level on feed and water intakes, digestibility, thermo-respiratory response and some blood constituents in sheep. 6 th Sci. Cong. Egyptian Society for Cattle Diseases, 4-6 Nov. 2001, Assiut, Egypt.

Kobeisy, M. A., I. A. Salem, M. Zenhom and M. Hayder, 1997. The effect of giving ascorbic acid on some physiological and hematological parameters of suckling lambs exposed to solar radiation and exercise. Assiut Vet. Med. J. 37:120-132.

More, T. , A. K. Rai and M. Singh, 1980. Note on the effect of thermal exposure on body fluid composition of different breeds and breed crosses of sheep. Indian J. Anim. Sci., 50:207-209. 
NRC., 1985. Nutrient requirements of sheep (6 $6^{\text {th }}$ Ed) National Academy of Sciences, National Research Council, Washington, D. C., USA.

SAS., 1981. SAS user's guide, Statistics. SAS Inst. Inc., Cary, NC.,USA.

Subiyatno, A. D. N. Mowat and W. Yang. 1996. Metabolite and hormonal responses to glucose or propionate infusions in periparturient dairy cows supplemented with chromium. J. Dairy Sci., 79:1436-1445.

$$
\begin{aligned}
& \text { تأثير أضـافة الكروم على الأسـتجابة الحراريـة والتنفس وبعض مقاييس الدم فى الأغنـام } \\
& \text { المعرضة للأجهاد الرياضى تحت اشعة الشمس } \\
& \text { مصطفى قبيصى، إبراهيم عبد اللة و آدم عبد العزيز } \\
& \text { ا - قسم الإنتاج الحيوانس، كلية الزراعة، جامعة أسبيوط، أسبيوط، ب - قسم الإنتاج الحيوانسى، كلية النراعة، } \\
& \text { جامعة عدن، البين } \\
& \text { تبحث الدراسة تأثير الكروم فى العليقة على معدل التنفس وحرارة المستقيم والجلد وبعض مكونات الدم فى }
\end{aligned}
$$

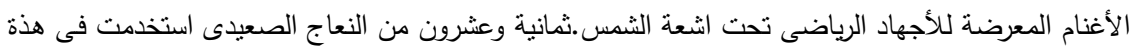

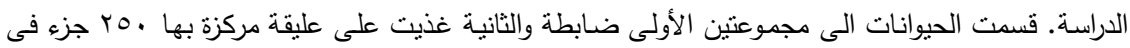

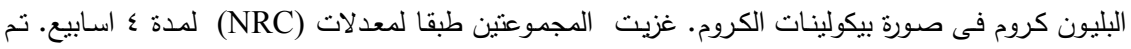

$$
\begin{aligned}
& \text { تعريض الحيوانات الى الأجهاد الرياضى تحت اشعة الشمس فى الاسبوع الأخير ومن الساعة الر-برا ظهرا } \\
& \text { لمرتين .تم تسجيل معدل التنفس وحرارة المستقيم والجلد قبل وبعد التعرض. كمـا اخذت عينات دم لتقدير } \\
& \text { الهيموجلوبين ومكونات السيرم من البروتين الكلى والألبيومين واليوريا والجلوكوز والكولسترول وانزيمات الكبد } \\
& \text { الناقلة للآمين AST \& ALT ـ تم تحليل البيانات بواسطة برنامج (SAS). أرتقع كل من معدل التنفس وحرارة }
\end{aligned}
$$

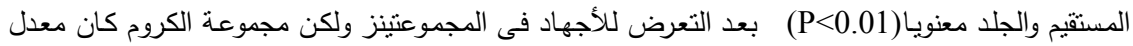

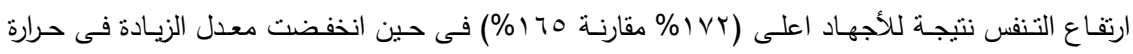

$$
\begin{aligned}
& \text { المستقيم (1. . مقارنة ـ (م ) ـ لم تتاثر بالمعاملة كل من الهيموجلوبين ومكونات السيرم من البروتين واليوريا. } \\
& \text { أزداد محتوى السيرم من الألبيومين نتيجة للأجهاد وكانت هذة الزيادة اكثر فى مجموعة الكروم. أدى الأجهاد }
\end{aligned}
$$

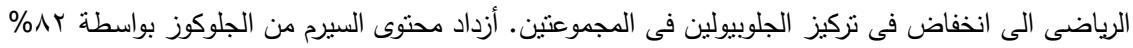

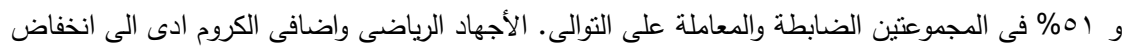

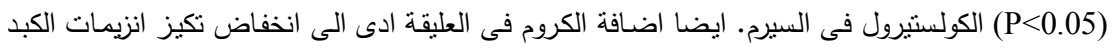

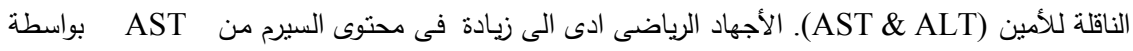

$$
\begin{aligned}
& \text { 9. T و r مرة فى الضابطة والمعاملة بالكروم على التوالى. }
\end{aligned}
$$

